\title{
COVID-19-Associated Encephalitis: Systematic Review of Case ReportsFindings on Cytokine- Immune-Mediated Inflammation as an Underlying Mechanism
}

\author{
Yusak M.T. Siahaan ( $\nabla$ yusak.siahaan@lecturer.uph.edu ) \\ Siloam Hospital Lippo Village, Tangerang, Banten, Indonesia \\ Vivien Puspitasari \\ Siloam Hospitals Lippo Village \\ Aristo Rinaldi Pangestu \\ Universitas Pelita Harapan Fakultas Kedokteran https://orcid.org/0000-0003-3785-3077
}

Research article

Keywords: COVID-19, SARS-Cov-2, encephalitis, cytokine storm, inflammation, infectionm encephalopathy

Posted Date: October 1st, 2020

DOl: https://doi.org/10.21203/rs.3.rs-65579/v1

License: (c) (i) This work is licensed under a Creative Commons Attribution 4.0 International License.

Read Full License 


\section{Abstract}

Background : Although severe acute respiratory syndrome coronavirus 2 (SARS-CoV-2) primarily attacks the respiratory system resulting to a disease called coronavirus disease 19 (COVID-19), several studies also reported the involvement of the central nervous system along the course of the disease, one of which manifest as encephalitis. This study aims to determine the clinical profile, laboratory, and imaging results of encephalitis associated with COVID-19.

Methods: Three databases namely, PubMed / Medline, Embase, and Scopus were systematically used in the search for this literature, in order to gather case reports and case series related to COVID-19associated encephalitis published from January 1, 2019 to July 20, 2020.

Result: There were 24 studies with 33 cases included in this review. The most reported neurological symptoms were disorientation / confusion (72.72\%), decreased consciousness (54.54\%), and seizures (27.27\%). The laboratory examination showed an increase in the levels of C-reactive protein (48.48\%), lactate dehydrogenase (30.3\%), and lymphophenia (27.27\%). The brain imaging examination did not show any pathological findings in half of the cases (51.51\%). EEG (electroencephalography) showed a generalized decrease in $45.45 \%$ of the cases. The CSF analysis showed an increase in the levels of protein $(42.42 \%)$ and lymphocytosis $(24.24 \%)$. Positive cerebrospinal fluid polymerase chain reaction (PCR) was only found in 3 cases, while the most widely used pharmacological agent was hyroxychloroquine (48.48\%). Intravenous steroids were given in 8 cases, while immunotherapy such as plasmapheresis and intravenous immunoglobulin were given in 10 cases. Fifteen patients were reported to be discharged from the hospital in stable conditions, while four mortality cases were recorded.

Conclusion: The clinical, laboratory, and imaging findings in this review supported the hypothesis that the process of cytokine-immune mediated inflammation was the cause of cerebral damage in COVID-19associated encephalitis, rather than direct invasion. However, due to the limited availabile facilities in this study, further research and examination are needed to confirm the hypothesis

\section{Background}

In January 2020, the severe acute respiratory syndrome coronavirus 2 (SARS-CoV-2) virus was first identified as the cause of pneumonia outbreak which developed into respiratory failure in Wuhan, China. ${ }^{1}$ Since then, the spread of the SARS-CoV-2 virus has expanded and led to an increase in the number of fatalities, hence it was declared a pandemic by World Health Organization (WHO) in March 2020. As of July 2020 , there were 15 million confirmed cases, with a mortality rate of more than 600,000 cases. $^{3}$

SARS-CoV-2 commonly attacks the respiratory system, causing pneumonia called coronavirus disease 2019 (COVID-19), with the initial symptoms being upper respiratory tract infections that rapidly develop into respiratory failure. ${ }^{4,5}$ Despite the clinical manifestations of COVID-19 in causing respiratory disorder, some studies reported that most patients also experienced neurological symptoms. ${ }^{6,7}$ The results of a 
study conducted by Helms et al showed that neurological symptoms were found in $84 \%$ of the patients that entered intensive care unit without sedation and neuromuscular blockers. They expressed central nervous dysfunction symptoms such as, agitation (69\%) and confusion (65\%). ${ }^{7}$ A systematic review conducted by Ghannam et al showed that $23 \%$ of the patients also had complications of encephalopathy or encephalitis. ${ }^{8}$ The results of both studies indicated the possibility of central nervous system involvement in the course of COVID-19 disease, with the presence of SARS-CoV-2 neurotropism. ${ }^{9}$

Previous studies have reported cases of encephalitis related to COVID-19, with varying clinical appearance, laboratorial and imaging findings. In this study, a systematic review was conducted with the aim of identifying the clinical profile and findings from laboratorial and imaging investigations on encephalitis associated with COVID-19.

\section{Methods}

This review conforms to the Preferred Reporting Items for Systematic reviews and Meta Analysis (PRISMA) statement (Fig. 1). ${ }^{10}$

\section{Search strategy}

The databases used in the search for this literature were, PubMed / Medline, Embase, and Scopus. The articles included were only those published in English from January 1, 2019 to July 20, 2020. The search terms used were, "COVID-19", "SARS-CoV-2", and "Encephalitis".

\section{Study selection}

The studies included in this review met the following criteria such as, prospective or retrospective case reports and case series from encephalitis patients related to COVID-19, while experimental studies were excluded. All potentially relevant articles were then screened for eligibility.

\section{Data extraction}

The extracted data included, bibliographic, demographics, symptom onset, clinical symptoms (respiratory and neurological), investigation results (laboratory, imaging, and electroencephalography), therapy, and the patient outcome.

\section{Results}

Twenty-four studies (33 patients) of encephalitis and COVID-19 cases were collected from 3 databases (Pubmed / Medline, Scopus, Embase). The patients were 11 female and 22 male with mean age of 47.9 (SD 16.65) years. The average onset of respiratory or systemic symptoms was 6 (SD 4.3) days, while that of central nervous system disorders appeared on the average of 11.1 (SD 7.85) days after respiratory / systemic symptoms, however, in two cases, neurologic symptom appeared 1-3 days earlier than respiratory symptoms. Demographic data were shown in Table 1. 
Table 1

Bibliographic and demographic data

\begin{tabular}{|c|c|c|c|c|c|}
\hline Author & Country & $\begin{array}{l}\text { Age and } \\
\text { gender }\end{array}$ & $\begin{array}{l}\text { Onset of } \\
\text { respiratory/systemic } \\
\text { symptom }\end{array}$ & $\begin{array}{l}\text { Neurologic } \\
\text { symptom } \\
\text { onset }\end{array}$ & Diagnosis \\
\hline $\begin{array}{l}\text { Duong et } \\
\mathrm{al}^{11}\end{array}$ & USA & $\begin{array}{l}41 \text { year } \\
\text { old } \\
\text { female }\end{array}$ & Not reported & Not reported & RT-PCR \\
\hline \multirow[t]{2}{*}{$\begin{array}{l}\text { Bernard- } \\
\text { Valnet et } \\
\mathrm{al}^{12}\end{array}$} & Switzerland & $\begin{array}{l}64 \text { year } \\
\text { old } \\
\text { female }\end{array}$ & 5 days & $\begin{array}{l}\text { Acutely (not } \\
\text { specified) }\end{array}$ & RT-PCR \\
\hline & & $\begin{array}{l}67 \text { year } \\
\text { old } \\
\text { female }\end{array}$ & 17 days & $\begin{array}{l}\text { Few hours } \\
\text { before } \\
\text { admission }\end{array}$ & RT-PCR \\
\hline Ye et $\mathrm{al}^{13}$ & China & $\begin{array}{l}\text { Male } \\
\text { (age not } \\
\text { reported) }\end{array}$ & 4 days & $\begin{array}{l}\text { Acutely (not } \\
\text { specified) }\end{array}$ & RT-PCR \\
\hline $\begin{array}{l}\text { McAbee et } \\
\mathrm{al}^{14}\end{array}$ & USA & $\begin{array}{l}\text { 11-year- } \\
\text { old boy }\end{array}$ & 2 days & $\begin{array}{l}\text { Acutely (not } \\
\text { specified) }\end{array}$ & RT-PCR \\
\hline \multirow[t]{2}{*}{$\begin{array}{l}\text { Andriuta et } \\
\text { al }{ }^{15}\end{array}$} & France & $\begin{array}{l}\text { Middle- } \\
\text { aged } \\
\text { female }\end{array}$ & 7 days & $\begin{array}{l}\text { Progressively } \\
\text { developed on } \\
\text { day } 16 \text { of } \\
\text { admission }\end{array}$ & RT-PCR \\
\hline & & $\begin{array}{l}\text { Middle- } \\
\text { aged } \\
\text { male }\end{array}$ & NR & NR & RT-PCR \\
\hline $\begin{array}{l}\text { Chaumont } \\
\text { et } \mathrm{al}^{16}\end{array}$ & France & $\begin{array}{l}\text { 69-year- } \\
\text { old male }\end{array}$ & 7 days & $\begin{array}{l}1 \text { day before } \\
\text { admission }\end{array}$ & RT-PCR/CT \\
\hline $\begin{array}{l}\text { Sohal et } \\
\text { al }^{17}\end{array}$ & USA & $\begin{array}{l}\text { 72-year- } \\
\text { old male }\end{array}$ & NR & $\begin{array}{l}\text { Day } 3 \text { of } \\
\text { admission }\end{array}$ & RT-PCR \\
\hline $\begin{array}{l}\text { Pilotto et } \\
\text { al }^{18}\end{array}$ & Italy & $\begin{array}{l}\text { 60-year- } \\
\text { old male }\end{array}$ & 2 days & $\begin{array}{l}5 \text { days before } \\
\text { admission }\end{array}$ & RT-PCR \\
\hline $\begin{array}{l}\text { Al-olama et } \\
\text { al }^{19}\end{array}$ & UEA & $\begin{array}{l}\text { 36-year- } \\
\text { old male }\end{array}$ & 2 days & $\begin{array}{l}4 \text { days after } \\
\text { respiratory } \\
\text { symptom }\end{array}$ & RT-PCR \\
\hline $\begin{array}{l}\text { Moriguchi } \\
\text { et } \mathrm{al}^{20}\end{array}$ & Japan & $\begin{array}{l}\text { 24-year- } \\
\text { old male }\end{array}$ & 1 day & $\begin{array}{l}9 \text { days after } \\
\text { respiratory } \\
\text { symptom }\end{array}$ & $\begin{array}{l}\text { CT-Scan/RT- } \\
\text { PCR CSF }\end{array}$ \\
\hline $\begin{array}{l}\text { Vandervorst } \\
\text { et } \mathrm{al}^{21}\end{array}$ & Belgium & $\begin{array}{l}\text { 29-year- } \\
\text { old male }\end{array}$ & 7 days & $\begin{array}{l}10 \text { days after } \\
\text { respiratory } \\
\text { symptom }\end{array}$ & RT-PCR \\
\hline
\end{tabular}

USA: United States of America, UK: United Kingdom, NR: not reported, RT-PCR: reverse transcription 


\begin{tabular}{|c|c|c|c|c|c|}
\hline Author & Country & $\begin{array}{l}\text { Age and } \\
\text { gender }\end{array}$ & $\begin{array}{l}\text { Onset of } \\
\text { respiratory/systemic } \\
\text { symptom }\end{array}$ & $\begin{array}{l}\text { Neurologic } \\
\text { symptom } \\
\text { onset }\end{array}$ & Diagnosis \\
\hline $\begin{array}{l}\text { Wong et } \\
\mathrm{al}^{22}\end{array}$ & UK & $\begin{array}{l}\text { 40-year- } \\
\text { old male }\end{array}$ & 10 days & $\begin{array}{l}\text { Day } 3 \text { of } \\
\text { admission }\end{array}$ & RT-PCR \\
\hline \multirow[t]{2}{*}{$\begin{array}{l}\text { Zandifar et } \\
\mathrm{al}^{23}\end{array}$} & Iran & $\begin{array}{l}\text { 49-year- } \\
\text { old male }\end{array}$ & 2 days & $\begin{array}{l}\text { Acutely (not } \\
\text { specified) }\end{array}$ & $\begin{array}{l}\text { Clinical, } \\
\text { imaging, and } \\
\text { exclusion other } \\
\text { possibilities }\end{array}$ \\
\hline & & $\begin{array}{l}\text { 39-year- } \\
\text { old male }\end{array}$ & 5 days & $\begin{array}{l}\text { Day } 3 \text { of } \\
\text { admission }\end{array}$ & RT-PCR \\
\hline $\begin{array}{l}\text { Farhadian } \\
\text { et } \mathrm{al}^{24}\end{array}$ & USA & $\begin{array}{l}\text { 78-year- } \\
\text { old } \\
\text { female }\end{array}$ & 2 days & $\begin{array}{l}3 \text { days before } \\
\text { admission }\end{array}$ & RT-PCR \\
\hline $\begin{array}{l}\text { Chalil et } \\
\mathrm{al}^{25}\end{array}$ & Canada & $\begin{array}{l}\text { 48-year- } \\
\text { old } \\
\text { female }\end{array}$ & 14 days & $\begin{array}{l}\text { Day } 15 \text { of } \\
\text { admission }\end{array}$ & $\begin{array}{l}\text { RT-PCR + CT- } \\
\text { Scan }\end{array}$ \\
\hline $\begin{array}{l}\text { Afshar et } \\
a^{26}\end{array}$ & Iran & $\begin{array}{l}\text { 39-year- } \\
\text { old } \\
\text { female }\end{array}$ & 9 days & $\begin{array}{l}1 \text { day after } \\
\text { respi }\end{array}$ & $\begin{array}{l}\text { Clinical, } \\
\text { imaging, and } \\
\text { serology }\end{array}$ \\
\hline \multirow[t]{2}{*}{$\begin{array}{l}\text { Bodro et } \\
\mathrm{al}^{27}\end{array}$} & Spain & $\begin{array}{l}\text { 25-year- } \\
\text { old male }\end{array}$ & 1 day & $\begin{array}{l}12 \text { hours } \\
\text { respiratory } \\
\text { symptom }\end{array}$ & RT-PCR \\
\hline & & $\begin{array}{l}\text { 49-year- } \\
\text { old male }\end{array}$ & 7 days & $\begin{array}{l}\text { Few hours } \\
\text { after } \\
\text { admission }\end{array}$ & RT-PCR \\
\hline Abdi et $\mathrm{al}^{28}$ & Iran & $\begin{array}{l}\text { 58-year- } \\
\text { old male }\end{array}$ & No complaint & $\begin{array}{l}1 \text { month, } \\
\text { progressive in } \\
2 \text { days }\end{array}$ & RT-PCR \\
\hline $\begin{array}{l}\text { Dellamare } \\
\text { et } \mathrm{al}^{29}\end{array}$ & France & $\begin{array}{l}\text { 51-year- } \\
\text { old male }\end{array}$ & 10 days & $\begin{array}{l}11 \text { days } \\
\text { respiratory } \\
\text { symptom }\end{array}$ & RT-PCR \\
\hline $\begin{array}{l}\text { Huang et } \\
\mathrm{al}^{30}\end{array}$ & USA & $\begin{array}{l}40 \text {-year- } \\
\text { old } \\
\text { female }\end{array}$ & NR & NR & RT-PCR \\
\hline Khoo et al ${ }^{31}$ & UK & $\begin{array}{l}65 \text {-year- } \\
\text { old } \\
\text { female }\end{array}$ & $\begin{array}{l}\text { History of } \\
\text { respiratory } \\
\text { symptom } 2 \text { weeks } \\
\text { before admission }\end{array}$ & $\begin{array}{l}7 \text { days before } \\
\text { admission }\end{array}$ & RT-PCR \\
\hline $\begin{array}{l}\text { Zambreanu } \\
\text { et } \mathrm{al}^{32}\end{array}$ & UK & $\begin{array}{l}\text { 66-year- } \\
\text { old } \\
\text { female }\end{array}$ & NR & $\begin{array}{l}\text { Few hours } \\
\text { before } \\
\text { admission }\end{array}$ & RT-PCR \\
\hline
\end{tabular}

USA: United States of America, UK: United Kingdom, NR: not reported, RT-PCR: reverse transcription 


\begin{tabular}{|c|c|c|c|c|c|}
\hline Author & Country & $\begin{array}{l}\text { Age and } \\
\text { gender }\end{array}$ & $\begin{array}{l}\text { Onset of } \\
\text { respiratory/systemic } \\
\text { symptom }\end{array}$ & $\begin{array}{l}\text { Neurologic } \\
\text { symptom } \\
\text { onset }\end{array}$ & Diagnosis \\
\hline $\begin{array}{l}\text { Panariello } \\
\text { et } \mathrm{al}^{33}\end{array}$ & Italy & $\begin{array}{l}\text { 23-year- } \\
\text { old male }\end{array}$ & NR & 3 days & RT-PCR \\
\hline \multirow[t]{6}{*}{$\begin{array}{l}\text { Dogan et } \\
\mathrm{al}^{34}\end{array}$} & Turkey & $\begin{array}{l}\text { 49-year- } \\
\text { old male }\end{array}$ & NR & NR & RT-PCR \\
\hline & & $\begin{array}{l}\text { 59-year- } \\
\text { old male }\end{array}$ & NR & NR & RT-PCR \\
\hline & & $\begin{array}{l}\text { 59-year- } \\
\text { old male }\end{array}$ & NR & NR & RT-PCR \\
\hline & & $\begin{array}{l}\text { 51-year- } \\
\text { old } \\
\text { female }\end{array}$ & NR & NR & RT-PCR \\
\hline & & $\begin{array}{l}\text { 55-year- } \\
\text { old male }\end{array}$ & NR & NR & RT-PCR \\
\hline & & $\begin{array}{l}\text { 22-year- } \\
\text { old male }\end{array}$ & NR & NR & RT-PCR \\
\hline
\end{tabular}

The most common respiratory / systemic symptoms (Table 2) were fever (54.54\%), fatigue / myalgia (48.48\%), cough (42.42\%), and shortness of breath (30.30\%). The most prominent symptoms of the central nervous system were disorientation / confusion (72.72\%), lost of consciousness (54.54\%), and seizures (27.27\%). On physical examination, extensor plantar response was found in $18.18 \%$ of the cases, the meningeal irritation sign and motor weakness were found in $12.12 \%$ of the cases respectively. In laboratory examinations, the most frequently recorded results were, an increase in C-reactive protein (CRP) levels (48.48\%), in lactate dehydrogenase (LDH) levels (30.3\%), and lymphophenia $(27.27 \%)$. 
Table 2

Summary of the case reports and case series findings

\begin{tabular}{|c|c|c|c|}
\hline & Variables & $\mathbf{n}$ & $\%$ \\
\hline \multirow[t]{13}{*}{ Comorbidities } & HT & 7 & 21.21 \\
\hline & DM & 4 & 12.12 \\
\hline & Obesity & 3 & 9.09 \\
\hline & CAD & 1 & 3.03 \\
\hline & ESKD & 1 & 3.03 \\
\hline & Kidney transplant & 1 & 3.03 \\
\hline & Dyslipidemia & 1 & 3.03 \\
\hline & $A D$ & 1 & 3.03 \\
\hline & OA & 1 & 3.03 \\
\hline & GERD & 1 & 3.03 \\
\hline & Closed-angle glaucoma & 1 & 3.03 \\
\hline & Autism & 1 & 3.03 \\
\hline & Substance abuse & 1 & 3.03 \\
\hline \multirow[t]{10}{*}{ COVID-19 systemic and respiratory symptom } & Fever & 18 & 54.54 \\
\hline & Cough & 14 & 42.42 \\
\hline & Nasal congestion & 3 & 9.09 \\
\hline & Sore throat & 1 & 3.03 \\
\hline & Dyspnea & 10 & 30.3 \\
\hline & Fatigue/myalgia & 16 & 48.48 \\
\hline & Headache & 10 & 30.3 \\
\hline & Anosmia & 3 & 3.03 \\
\hline & Ageusia & 2 & 6.06 \\
\hline & Diarrhea & 4 & 12.12 \\
\hline \multirow[t]{3}{*}{ Neurologic symptom } & Loss of consciousness & 18 & 54.54 \\
\hline & Disorientation/confusion & 24 & 72.72 \\
\hline & Hallucination & 4 & 12.12 \\
\hline
\end{tabular}




\begin{tabular}{|c|c|c|c|}
\hline & Variables & $\mathbf{n}$ & $\%$ \\
\hline & Psychotic & 2 & 6.06 \\
\hline & Stiff neck & 1 & 3.03 \\
\hline & Insomnia & 1 & 3.03 \\
\hline & Aphasia & 2 & 6.06 \\
\hline & Seizure & 5 & 15.15 \\
\hline & Tonic-clonic & 1 & 3.03 \\
\hline & Tonic & 1 & 3.03 \\
\hline & Myoclonic & 2 & 6.06 \\
\hline & Unspecified & & \\
\hline & Involuntary movement & 3 & 9.09 \\
\hline & Unsteadiness & 3 & 9.09 \\
\hline & Diplopia & 2 & 6.06 \\
\hline & Disfagia & 1 & 3.03 \\
\hline & Incontinence bowel/bladder & 1 & 3.03 \\
\hline Neurologic sign & Meningeal sign & 4 & 12.12 \\
\hline & Pupil anisocoria & 2 & 6.06 \\
\hline & Akinetic mutism & 3 & 9.09 \\
\hline & Motorik weakness & 1 & 3.03 \\
\hline & Tetraplegia & 1 & 3.03 \\
\hline & Paraplegia & 2 & 6.06 \\
\hline & Hemiplegia & & \\
\hline & Sensory deficit & 2 & 6.06 \\
\hline & Extensor plantar response & 6 & 18.18 \\
\hline & Photophobia & 1 & 3.03 \\
\hline & Visual field defect & 1 & 3.03 \\
\hline & Facial weakness & 1 & 3.03 \\
\hline & Tounge weakness & 1 & 3.03 \\
\hline
\end{tabular}




\begin{tabular}{|c|c|c|c|}
\hline & Variables & $\mathbf{n}$ & $\%$ \\
\hline & Nystagmus & 1 & 3.03 \\
\hline & Loss brainstem reflexes & 3 & 9.09 \\
\hline & Sensory hemineglect & 1 & 3.03 \\
\hline & Ataxia & 2 & 3.03 \\
\hline \multirow[t]{13}{*}{ Laboratory } & Lymphophenia & 9 & 27.27 \\
\hline & Leukocytosis & 8 & 24.24 \\
\hline & Leukopenia & 3 & 9.09 \\
\hline & Trombocytosis & 3 & 9.09 \\
\hline & Trombocytopenia & 3 & 9.09 \\
\hline & Elevated CRP & 16 & 48.48 \\
\hline & Elevated LDH & 10 & 30.3 \\
\hline & Elevated procalcitonin & 3 & 9.09 \\
\hline & Elevated ESR & 1 & 3.03 \\
\hline & Elevated D-dimer & 6 & 18.18 \\
\hline & Elevated CK & 3 & 9.09 \\
\hline & Elevated AST / ALT & 2 & 6.06 \\
\hline & Elevated LDH & 1 & 3.03 \\
\hline \multirow[t]{6}{*}{ Chest Imaging } & GGO + consolidation (CT-Scan) & 4 & $18.18 *$ \\
\hline & GGO without consolidation(CT-Scan) & 12 & $54.54 *$ \\
\hline & Infiltrate / consolidation (X-Ray) & 3 & $13.63^{*}$ \\
\hline & Subpleural condensation (USG) & 1 & $4.54^{\star}$ \\
\hline & Normal & 2 & $9.09 *$ \\
\hline & Not Reported & 11 & 33.33 \\
\hline \multirow[t]{2}{*}{ Brain Imaging } & Normal & 17 & 51.51 \\
\hline & Diffusie edema & 1 & 3.03 \\
\hline
\end{tabular}




\begin{tabular}{|c|c|c|c|}
\hline & Variables & $\mathbf{n}$ & $\%$ \\
\hline & Hyperintense & 3 & 9.09 \\
\hline & Thalamus & 2 & 6.06 \\
\hline & Cerebellar & 2 & 6.06 \\
\hline & Periventricular & 3 & 9.09 \\
\hline & Mesencephalic & 3 & 9.09 \\
\hline & Pons & 8 & 24.24 \\
\hline & White matter & 3 & 9.09 \\
\hline & \multicolumn{3}{|l|}{ Temporal lobe } \\
\hline & Hemorrhagic & 1 & 3.03 \\
\hline & Pallidum & 2 & 6.06 \\
\hline & Lobar & 4 & 12.12 \\
\hline & \multicolumn{3}{|l|}{ Sulcus (SAH) } \\
\hline & Contrast enhancement & 4 & 12.12 \\
\hline \multirow[t]{12}{*}{ CSF Studies } & Elevated WBC & 9 & 27.27 \\
\hline & Elevated neutrofil & 1 & 3.03 \\
\hline & Lymphocytosis & 8 & 24.24 \\
\hline & Elevated RBC & 5 & 15.15 \\
\hline & Elevated protein & 14 & 42.42 \\
\hline & Decreased glucose & 1 & 3.03 \\
\hline & Elevated pressure & 2 & 6.06 \\
\hline & Anti-neuronal autoantibodies & 1 & $12.5^{\star}$ \\
\hline & Positif & 7 & $87.5^{\star}$ \\
\hline & Negative & 25 & 75.75 \\
\hline & Not performed & & \\
\hline & Inflamatory cytokines & 7 & $100 *$ \\
\hline \multirow[t]{2}{*}{ CSF PCR } & Positive & 3 & 10.71 * \\
\hline & Negative & 25 & $89.28 *$ \\
\hline
\end{tabular}




\begin{tabular}{|lllc|}
\hline & Variables & $\mathbf{n}$ & \% \\
\hline & Not reported & 5 & 15.15 \\
\hline Electroencephalography (EEG) & Background slowing & 7 & 63.30 \\
& Focal focus & 1 & $9.09 *$ \\
& Frontal & 2 & $18.18^{\star}$ \\
& Temporal & & \\
\hline Normal & & \\
\hline Outcomes & Not reported & 1 & $9.09 *$ \\
\hline Discharged & 22 & 66.66 \\
\hline Death & 15 & $65.21^{\star}$ \\
\hline Still in treatment & 4 & $17.39 *$ \\
\hline Not reported & 4 & $17.39 *$ \\
\hline
\end{tabular}

The chest imaging examination was reported in 22 studies, with ground glass opacities $(72.72 \%)$ as the dominant result, which was typically found in COVID-19 cases. The brain imaging mostly did not show a pathological picture (51.51\%). Hyperintensity in the white matter was found in $24.24 \%$ of the cases. Electroencephalography (EEG) was carried out in 11 cases with the most common result found to be generalized slowing (45.45\%). The most commonly found cerebrospinal fluid (CSF) in the analysis were proteinoracchia (42.42\%) and lymphocytosis $(24.24 \%)$. All the 5 studies that recorded proinflammatory cytokine analysis in CSF (interleukin- $6^{18,24,27,33,34}$, interleukin $1 \beta^{27}$, interleukin-8 ${ }^{18,24}$, tumor necrosis factor $\left.\mathrm{a}^{18}\right)$ showed significant increase (100\%). Anti neuronal autoantibodies were only found in 1 case $(\mathrm{N}$ methyl-D-Aspartate receptor $)^{33}$ out of the 8 cases that were examined $2,18,27,29,31,32,33$ (12.5\%). SARS-CoV2 polymerase chain reaction (PCR) examination on CSF was carried out in 28 cases, with positive results in 3 cases. ${ }^{19,20,30}$ CSF and PCR examination of other viruses such as, herpes simplex virus (HSV), human herpes virus 6 (HHV 6), cytomegalovirus (CMV), varicella-zooster virus (VZV) produced negative results.

The most used pharmacological agents (Table 3 ) were hyroxychloroquine (48.48\%), azithromycin (27.27\%), and favipiravir (24.24\%). Intravenous steroids were given in 8 cases ( 5 methylprednisolone ${ }^{18,26,29,31,32}, 2$ dexamethasone ${ }^{28,33}, 1$ unspecified $\left.^{21}\right)$, while immunotherapy such as, plasmapheresis and intravenous immunoglobulin (IVIG) were given to 10 patients (6 plasmapheresis ${ }^{34}, 4$ IVIg ${ }^{18,26,29,32}$ ). Fifteen patients $(65.21 \%)$ were reported to be discharged from the hospital in stable conditions, while four mortality cases $(17.39 \%)^{17.23 .28}$ were recorded. 
Table 3

Pharmacological agents used in studies

\begin{tabular}{|c|c|c|c|}
\hline Classification & Pharmacological agent & $\mathbf{n}$ & $\%$ \\
\hline \multirow[t]{8}{*}{ Antiviral } & Acyclovir & $9^{a}$ & 27.27 \\
\hline & Atazanavir & 1 & 3.03 \\
\hline & Arbidol & 1 & 3.03 \\
\hline & Oseltamivir & $1^{\mathrm{a}}$ & 3.03 \\
\hline & Darunavir/Cobicistat & 1 & 3.03 \\
\hline & Lopinavir & 2 & 6.06 \\
\hline & Ritonavir & 2 & 6.06 \\
\hline & Favipiravir & 8 & 24.24 \\
\hline \multirow[t]{9}{*}{ Antibiotic } & Ceftriaxone & $6\left(4^{a}\right)$ & 18.18 \\
\hline & Vancomycin & $3\left(1^{\mathrm{a}}\right)$ & 9.09 \\
\hline & Levofloxacin & 1 & 3.03 \\
\hline & Linezolide & 1 & 3.03 \\
\hline & Piperacillin-tazobactam & 1 & 3.03 \\
\hline & Amoxicillin & $2\left(1^{a}\right)$ & 6.06 \\
\hline & Ampicillin & $3^{a}$ & 9.09 \\
\hline & Meropenem & 1 & 3.03 \\
\hline & Azithromycin & 9 & 27.27 \\
\hline \multirow[t]{4}{*}{ Antiepileptic drug } & Levetiracetam & 6 & 18.18 \\
\hline & Clonazepam & 2 & 12.12 \\
\hline & Valporate & 3 & 9.09 \\
\hline & Midazolam & 2 & 6.06 \\
\hline \multirow[t]{5}{*}{ Other } & Hydroxychloroquine & 16 & 48.48 \\
\hline & Mannitol & 1 & 3.03 \\
\hline & Norepinephrine & 1 & 3.03 \\
\hline & Methylprednisolone & 6 & 18.18 \\
\hline & Dexamethasone & 2 & 6.06 \\
\hline
\end{tabular}




\begin{tabular}{|llll|}
\hline Classification & Pharmacological agent & $\mathbf{n}$ & \% \\
\hline Nebivolol & 1 & 3.03 \\
\hline Amlodipine & 1 & 3.03 \\
\hline Quetiapine & 2 & 6.06 \\
\hline Acipiprazole & 1 & 3.03 \\
\hline Haloperidol & 2 & 6.06 \\
\hline Promazine & 1 & 3.03 \\
\hline Paracetamol & 1 & 3.03 \\
\hline Tocilizumab & 2 & 6.06 \\
\hline Heparin, protamine sulfat & $1^{\mathrm{a}}$ & 3.03 \\
\hline Vitamin B \& C & 1 & 3.03 \\
\hline Plasmapharesis & 6 & 18.18 \\
\hline IVIG & 4 & 12.12 \\
\hline
\end{tabular}

\section{Discussion}

\section{Systemic review analysis}

Although the main target of organ damage by SARS-CoV-2 was the respiratory system, based on several previous studies, patients also experienced neurological problems ranging from the mild manifestations (such as, headaches and dizziness) to life-threatening complications (such as, cerebrovascular disorders and encephalitis). ${ }^{6}$ The study conducted by Helms et al. showed that agitation (69\%) was the common complaint found in COVID-19 patients receiving treatment in the Intensive Care Unit (ICU). ${ }^{7}$

Based on this review, the common symptoms found in encephalitis patients were disorientation or confusion (72.72\%), decreased consciousness (54.54\%), and seizures $(27.27 \%)$. These symptoms indicated damages in the central nervous system, especially the cerebral cortex, typically found in acute encephalitis. This result was similar to the clinical manifestations of encephalitis in which disorientation was the most common symptom reported in patients with positive HSV and PCR (92\%). ${ }^{35}$ In COVID-19associated encephalitis, the manifestations of seizures and headaches were found in $27.27 \%$ and $30.3 \%$ of the cases, while HSV encephalitis seizures were found in $56 \%$ of the cases and headaches in $83 \%$ of the cases. ${ }^{35}$ Abnormal behaviour that was characteristically found in HSV was rarely found in COVID-19 encephalitis. The clinical appearance of COVID-19-associated encephalitis was similar to MERS-CoV 2associated encephalitis, with the symptoms of upper respiratory tract infection (fever, cough, fatigue) and a decrease in mental status and rapid respiratory failure. ${ }^{36}$ Meningeal irritation sign was only found in 4 
cases $(12.12 \%)$, which showed that the pathological process was more dominant in the cortex than in the meninges. This also indicated that the involvement of meninges in COVID-19-associated encephalitis was less common than HSV, as the meningeal irritation signs appearing in $29 \%$ of HSV cases. ${ }^{35}$ However, these results can also be produced due to the loss of meningeal irritation in severe states of consciousness.

The laboratory results showed an increase in inflammatory markers such as, CRP (48.48\%), LDH (30.3\%), and lymphophenia (27.27\%). This result was found to be higher than the general systematic review of COVID-19 studies conducted by Rodriguez-Morales et $\mathrm{al}^{37}$, while the increase in CRP and LDH were found in $22.2 \%$ and $6.3 \%$ of the cases respectively. These differences were due to the frequent and severe inflammatory reaction in COVID-19-associated encephalitis. Wang's research showed that CRP levels in the group with severe symptoms were significantly higher than those with moderate or mild symptoms ( $54.15 \mathrm{mg} / \mathrm{dL}$ vs $16.76 \mathrm{mg} / \mathrm{dL}$ vs $1.52 \mathrm{mg} / \mathrm{dL}, \mathrm{p}<0.05) .{ }^{38}$ The condition of lymphopenia indicated the involvement of $\mathrm{T}$ lymphocytes, which caused CD4 and CD8 ${ }^{37,39}$ cell depletion. Lymphopenia occurred due to lymphocyte sequestration at specific target organs such as, the lungs, gastrointestinal tract, and lymphoid tissue, via the activation of ACE2 receptors by SARS-CoV-2. Other hypotheses indicated that SARS-CoV-2 had a similar phenotype and mechanism as SARS-COV, which included the tendency for direct bone marrow suppression, the immune-mediated destruction of lymphocytes ${ }^{40,41,42}$, and lymphopenia manifestation ${ }^{40}$

The brain imaging studies in some of the cases did not show significant pathologic features $(51.51 \%)$. The most common pathological common finding was the diffuse hyperintensity of T2 / fluid attenuated inversion recovery (FLAIR), with location most frequently in white matter $(24.24 \%)$. These results were similar with the systematic review conducted by Katal et al, where most of the normal magnetic resonace imaging (MRI) images (41\%) were found in COVID-19 patients. Therefore, the results of neuroimaging encephalitis associated with COVID-19 in this review resembled with those of encephalopathy / encephalitis in the previous coronavirus outbreak. Two severe acute respiratory syndrome coronavirus (SARS-CoV) cases accompanied by severe neurological symptoms in the form of decreased consciousness and seizures showed a normal picture of neuroimaging. ${ }^{44,45}$ The research conducted by Arabi et al in 2016 reported in the three cases of middle east respiratory syndrome coronavirus (MERSCoV) patients and evaluation by MRI showed that the hyperintense lesions on T2 spread widely and bilaterally in white matter and subcortical areas, frontal lobes, temporal, parietal, and basal ganglia, as well as the corpus callosum. ${ }^{36}$ The neuroimaging findings suggested possible similarities in the pathomechanism of the central nervous system involvenent in SARS-CoV-2, SARS-CoV, and MERS-CoV.

The electroencephalography (EEG) examination was carried out on 11 cases, with the result showing a non-specific general slowing EEG (63.30\%). Meanwhile, the epileptiform foci were found in 3 cases $(27.27 \%), 2$ in the temporal and 1 in the frontal lobe. This was consistent with the study conducted by Canham et al, which stated that the predominant EEG features in severe COVID-19 patient experienced a general slowing. ${ }^{47}$ These findings indicated that the mechanism of central nervous system in COVID-19 
was diffuse and widespread, in contrast to encephalitis caused by HSV, where a typical 2-3 Hz periodic lateralized epileptiform discharges, originating from the temporal lobes. ${ }^{48}$ The CSF analysis showed increase in protein level (42.42\%), white blood cells (27.27\%), and lymphocytes (24.24\%) case. In addition, the cerebrospinal fluid (CSF) and polymerase chain reaction (PCR) examination showed a negative result for SARS-CoV-2, due to the direct invasion of the virus.

The large variety of pharmacological agents was as a result of the dynamic changes of COVID-19 guideline and protocols in each center. The use of acyclovir and ceftriaxone were generally given as the empirical therapy, and was stopped when there was no evidence of a bacterial infection or HSV. There was an increase in proinflammatory cytokines in $\operatorname{CSF}^{18,24,27,33,34}$, indicating the possible role of intravenous steroids and immunotherapy (IVIg and plasmapheresis) in the management of encephalitis associated with COVID-19. The methylprednisolone and IVIg therapy given in the 4 cases of COVID-19associated encephalitis ${ }^{18,26,29,32}$ showed a positive response, with 3 patients discharged in stable conditions ${ }^{18,29,32}$, while 1 was still in care with significant improvement. ${ }^{26} \mathrm{~A}$ study conducted by Dogan et al stated that plasmapheresis therapy showed dramatic improvements in both clinical and laboratory findings. ${ }^{34}$ This positive result supported the theory of a cytokine-mediated hyperinflammatory response as the basis for pathomechanism of COVID-19-associated encephalitis. ${ }^{18}$

\section{Cytokine-immune-mediated inflammation as the underlying patomechanism in SARS-CoV-2-associated inflammation}

The mechanism of encephalitis in COVID-19 was found to be unclear, however, previous studies had indicated that there was a neurotropism of the SARS-CoV-2 virus which allowed the invasion of the virus towards the central nervous system. There were two pathways that allowed this invasion, namely through the systemic circulation and the cribriform plate of ethmoid bone. ${ }^{49}$ The SARS-CoV-2 virus bound with the angiotensin-converting enzyme $2\left(\mathrm{ACE}_{2}\right)$ receptor via spike protein $\mathrm{S} 1$, allowing the attachment of virions to cell membranes. ${ }^{49,50}$ The systemic dissemination resulted from the attachment of SARS-CoV- 2 to the ACE2 receptor in the capillary endothelium. ${ }^{50} \mathrm{ACE}_{2}$ expression in glia cells and neurons was the pathway mechanism for cerebral damage. ${ }^{49,50}$ The occurrence of hyposmia or anosmia due to the spread of the virus in the olfafactory bulb via the cribroform plate was the alternative pathway for invading the central nervous system. ${ }^{49}$

Furthermore, this study opposed that the pathomechanism of central nervous system damage in COVID19-associated encephalitis was caused by direct invasion of the virus. The MRI images that were predominantly normal in this study were consistent with the features of autoimmune encephalitis, while based on previous research, $60 \%$ of the $\mathrm{N}$-methyl-D-Aspartate receptor (NMDA-R) encephalitis wwere generally normal. ${ }^{51}$ EEG findings indicated diffuse cerebral abnormalities, possibly the results of severe and extensive inflammation. CSF analysis showed that the inflammatory process (denote an proteinorrachia) mediated by cytokines, was supported by the results of increased proinflammatory in the CSF. The predominantly negative CSF PCR (89\%) against SARS-CoV-2 opposed the hypothesis regarding 
direct viral invasion of the brain as the cause of encephalitis. The possibility of an autoimmune mechanism was considered based on several previous studies linking COVID-19 with GBS. ${ }^{52}$ There were two reported cases with autoimmune features namely, the NMDA-R ${ }^{33}$ and limbic encephalitis (T2 hyperintense signal abnormalities in limbic lobes, bilateral medial thalamus, and frontal white matter). ${ }^{32}$ The anti-neuronal autoantibodies were only positive in 1 case (NMDA-R) ${ }^{33}$ of the 8 cases examined $(12.5 \%)$, indicating the emergence of new antigens, mediating immune reactions to the central nervous system. The positive response showed by COVID-19 patients towards intravenous steroid therapy and immunotherapy (IVIg and plasmapheresis) commonly used in in the autoimmune conditions such as, myasthenia gravis and GBS proved that there was an immune process in the occurrence of encephalitis. ${ }^{53}$

Based on the theories from the previous studies ${ }^{54,55,56}$ the pathomechanism of immune-mediated cerebral damage in COVID-19-associated encephalitis were illustrated (Fig. 2). The binding of SARS-CoV2 to $A C E 2$ receptor via spike protein, caused $A C E_{2}$ downregulation ${ }^{50,54}$, followed by an increase in ACE / Angiotensin II / AT1R axis, and a decrease in ACE2 / Mas receptor (MaSR) axis. ${ }^{54}$ Consequently, these resulted to the activation of the nuclear factor kappa B (NF-kappa B) pathway, Mitogen-Activated Protein Kinase (MAPK) pathway, upregulation of tumor growth factor beta (TGF-beta) accompanied by downregulation of anti-inflammatory cytokine IL-10. ${ }^{54.55}$ Therefore, the increased proinflammatory pathways rised the levels of monocyte chemotactic protein 1 (MCP-1) ), vascular cell adhesion molecule 1 (VCAM-1), selectin-E, and interlekukin 6 (IL-6). ${ }^{55}$ The IL-6 was found to be the core part of the cytokine storm. ${ }^{54,55,56}$ The IL- 6 activated the CD $4+T$ cells into Th17, which aggravated the pro-inflammatory cytokines namely, IL-17, IL-21, and IL-22. ${ }^{57}$ The cytokine storms and the endothelial dysfunction caused blood-brain-barrier damage, making it easier for pro-inflammatory cytokines to enter the brain parenchyma and also caused further neural damage. ${ }^{56}$

It was previously confirmed that the pathomechanism underlying COVID-19 encephalitis was a cytokineimmune-inflammatory process. ${ }^{18,34,56}$ However, further research was needed to explain and confirm this hypothesis.

The limitation encountered was due to the large variety of case reports and some investigation such as, EEG and PCR which were not reported in all studies. The negative CSF and PCR pointed out that the cause of COVID-19 encephalitis was not a result of viral direct invasion. The inflammatory markers and the anti-neuronal autoantibodies assessment had only been done in few studies, therefore, it was inconclusive that the cause of COVID-19 encephalitis was cytokine-immune mediated inflammatory process.

\section{Conclusion}

The clinical, laboratory, and imaging findings in this review supported the hypothesis that the process of cytokine-immune mediated inflammation was the cause of cerebral damage in COVID-19-associated 
encephalitis, rather than direct invasion. Several studies reported the benefits of intravenous steroid therapy and immunotherapy in COVID-19-associated encephalitis treatment. Although, cytokine-immunemediated inflammation was suspected to cause encephalitis, which was inconclusive due to the limited availabile facilities. Therefore, further examination and research are needed to confirm this hypothesis.

\section{Abbreviations}

$\mathrm{ACE}_{2}$ : Angiotensin-converting enzyme 2

AD: Alzheimer's Disease

ALT:Alanine transaminase

AST: Aspartate transaminase

CAD: Coronary artery disease

CK: Creatinine kinase

CMV: Cytomegalovirus

COVID-19: coronavirus disease 19

CRP: C-reactive protein

CSF: Cerebrospinal fluid

DM: Diabetes mellitus

ESKD: End stage kidney disease

ESR: Eryhtrocyte sedimentation rate

FLAIR: Fluid attenuated inversion recovery

GERD: Gastroesophageal reflux disease

GGO: Ground glass opacity

HHV-6: Human herpes virus 6

HT: Hypertension

HSV: Herpes simplex virus

IL-6: Interleukin 6 
LDH: Lactate dehydrogenase

MasR: Mas receptor

MCP-1: Monocyte chemotactic protein 1

MERS-CoV: Middle east respiratory syndrome coronavirus

MRI: Magnetic resonance imaging

NMDA-R: N-methyl-D-Aspartate receptor

OA:Osteoarthritis

PCR: Polymerase chain reaction

RBC: Red blood cell

SAH: Subarachnoid hemorrhage

SARS-CoV: Severe acute respiratory syndrome coronavirus

SARS-CoV-2: Severe acute respiratory syndrome coronavirus 2

USG: Ultrasonography

VCAM-1: vascular cell adhesion molecule 1

VZV: Varicella-zooster virus

WBC: White blood cell

\section{Declarations}

\section{Ethics approval and consent to participate}

Not applicable

\section{Consent for publication}

Not applicable

\section{Avaiability of data and material}


All data generated or analysed during this study are included in this published article (and its supplementary information files)

\section{Competing interests}

The authors declare that they have no competing interests

\section{Funding}

There were no funding sources.

\section{Author's contribution}

This study was designed, directed and coordinated by Y.M.T.S., as the principal investigator, provided conceptual and technical guidance for all aspects of project. V.P. and A.P. contributed equally to manuscript conceptualization, writing, editing, and review for submission. All authors read and approved final manuscript

\section{Acknowledgements}

We thank Dr. Retno Jayantri Ketaren for proofreading the manuscript.

\section{References}

1. Novel Coronavirus (2019-nCoV) situation report-1. https://www.who.int/docs/defaultsource/coronaviruse/situation-reports/20200121-sitrep-1-2019-ncov.pdf?sfvrsn=20a99c10_4 (Accessed on 22 July 2020) 2020.

2. Cucinotta D, Vanelli M. WHO Declares COVID-19 a Pandemic. Acta Bio Med. 2020; 91(1):157-60.

3. Johns Hopkins University and Medicine. Coronavirus resource center. Coronavirus.jhu.edu/map.html (accessed on July 22, 2020).

4. Zheng J. SARS-CoV-2: an emerging coronavirus that causes a global threat. Int J Biol Sci 2020; 16(10):1678-85.

5. Pascarella G, Strumia A, Pilliego C, Bruno F, Buono RD, Costa F, Scarlata S. COVID-19 diagnosis and management: a comprehensive review. Journal of Internal Medicine 2020; 288(2): 192-206.

6. Mao L, Jin H, Wang M, Hu Y, Chen S, He Q et al. Neurologic manifestations of hospitalized patients with coronavirus disease 2019 in Wuhan, China. JAMA Neurology 2020; 77(6):683-690.

doi:10.1001/jamaneurol.2020.1127 
7. Helms J, Kremer S, Merdji, Clere-Jehl R, Schenck M, Kummerlen C, et al. Neurologic features in severe SARS-CoV-2 infection. N Engl J Med 2020; 382:2268-2270. DOI: 10.1056/NEJMc2008597

8. Ghannam M, Alshaer Q, Al-Chalabi M, Zakarna L, Robertson J, Manousakis G. Neurological involvement of coronavirus disease 2019: a systematic review. J Neurol 2020; 19:1-19.

9. Baing AM, Khaleew A, Ali U, Syeda H. Evidence of the COVID-19 virus targeting the CNS: tissue distribution, host-virus interaction, and proposed neurotropic mechanism. ASC Chem Neurosci 2020; 11(7):995-998.

10. Hutton B, Salanti G, Caldwell DM, Chaimani A, Schmid CH, Cameron C, et al. The PRISMA extension statement for reporting of systematic reviews incorporating network meta-analyses of health care interventions: checklist and explanations. Ann Intern Med 2015; 162(11):777-84.

11. Duong L, Xu P, Liu A. Meningoencephalitis without respiratory failure in a young female patient with COVID-19 infection in Downtown Los Angeles, early April 2020. Brain, Behavior, and Immunity 2020; 87:33.

12. Bernard-Valnet R, Pizzarotti B, Anichini A, Demars $Y$, Russo E, Schmidhause M, et al. Two patients with acute meningoencephalitis concomitant with SARS-CoV-2 infection. European Journal of Neurology 2020; 10.1111/ene.14298.

13. Ye M, Ren Y, Lv T. Encephalitis as a clinical manifestation of COVID-19. Brain, Behavior, and Immunity 2020; 1591: 30465-30467.

14. McAbee GN, Brosgol Y, Pavlakis S, Agha R, Gaffoor M. Encephalitis Associated with COVID-19 Infection in an 11-Year-Old Child. Pediatric Neurology 2020; DOI:

10.1016/j.pediatrneurol.2020.04.013

15. Andriuta D, Roger P, Thibault W, Toublanc B, Sauzay C, Castelain S, et al. COVID-19 encephalopathy: detection of antibodies against SARS-CoV-2 in CSF. Journal of neurology 2020; DOI: 1007/s00415020-09975-1

16. Chaumont H, Etienne P, Roze E, Couratier C, Roger PM, Lannuzel A. Acute meningoencephalitis in a patient with COVID-19. Revue Neurologique 2020; 176: 519-521.

17. Sohal S, Mossammat M. COVID-19 Presenting with Seizures. IDCases 2020; 20: e00782.

18. Pilotto A, Odolini S, Masciocchi S, Comelli A, Volonghi I, Gazzina S, et al. Steroid-Responsive Encephalitis in Coronavirus Disease 2019. Annals of Neurology 2020; DOI: 10.1002/ana.25783.

19. Al-olama M, Rashid A, Garozzo D. COVID-19-associated meningoencephalitis complicated with intracranial hemorrhage: a case report. Acta Neurochirurgica 2020; 162: 1495-1499.

20. Moriguchi T, Harii N, Goto J, Harada E, Sugawara H, Takamino J, et al. A first case of meningitis/encephalitis associated with SARS-Coronavirus-2. International Journal of Infectious Diseases, 2020; 94: 55-58.

21. Vandervorst F, Gudolf K, Peeters I, Vanderhasselt T, Michiels K, Berends K, et al. Encephalitis associated with the SARS-CoV-2 virus: A case report. Interdisciplinary Neurosurgery: Advanced Techniques and Case Management 2020; DOI: 1016/j.inat.2020.100821 
22. Wong PF, Craig S, Newman P, Makan A, Srinivasan K, Crawford E, et al. A case of rhombencephalitis as a rare complication of acute COVID-19 infection. Clinical Medicine, 2020; 20: 293-294.

23. Zandifar S, Zandifar Z. Acute viral encephalitis associated with SARS-CoV-2. Ann Clin Case Rep 2020; 5:1845.

24. Farhadian S, Glick LR, Vogels CBF, Thomas J, Chiarella J, Casanovas-Massana A, et al. Acute encephalopathy with elevated CSF inflammatory markers as the initial presentation of COVID-19. BMC Neurology 2020; 20:248.

25. Chalil A, Baker CS, Johnson RB, Just C, Debicki DB, Mayich MS, et al. Acute hemorrhagic encephalitis related to COVID-19. Neurology Clinical Practice 2020; DOI: 10.1212/CPJ.0000000000000900

26. Afshar H, Yassin Z, Kalantari S, Aloosh O, Lotfi T, Moghaddasi M, et al. Evolution and resolution of brain involvement associated with SARSCoV2 infection: A close Clinical - Paraclinical follow up study of a case. Multiple Sclerosis and Related Disorders 2020; 43:102216.

27. Bodro M, Compta Y, Llanso L, Esteller D, Doncel-Moriano A, Mesa A. Increased CSF levels of IL-1 $\beta$, IL6 , and ACE in SARS-CoV-2-associated encephalitis. Neurol Neuroimmunol Neuroinflamm 2020; 7(5):1-4. DOI: 1212/NXI.0000000000000821

28. Abdi S, Ghorbani A, Fatehi F. The association of SARS-CoV-2 infection and acute disseminated encephalomyelitis without prominent clinical pulmonary symptoms. Journal of Neurological Sciences 2020; DOI: 10.1016/j.jns.2020.117001

29. Dellamare L, Gollion CM, Grouteau G, Rousset D, Jimena G, Roustan J. COVID-18-associated acute necrotizing encephalopathy successfully treated with steroids and polyvalent immunoglobulin with unusual IgG targeting the cerebral fibre network. J Neurol Neurosurg Psychiatry 2020; DOI: 1136/jnnp-2020-323678

30. Huang YH, Jiang D, Huang JT. SARS-CoV-2 detected in cerebrospinal fluid by PCR in a case of COVID-19 encephalitis. Brain, Behaviour, and Immunity 2020; DOI: 1016/j.bbi.2020.05.012

31. Khoo A, McLoughlin B, Cheema S, Well RS, Lambert C, Manji H, et al. Postinfectious brainstem encephalitis associated with SARS-CoV-2. J Neurol Neurosurg Psychiatry 2020;0:1-2.

DOI:10.1136/jnnp-2020-323816

32. Zambreanu L, Lightbody S, Bhandari M, Hoskote C, Kandil H, Houlihan CF, et al. A case of limbic encephalitis associated with asymptomatic COVID-19 infection. J Neurol Neurosurg Psychiatry 2020;0:1-2.doi:10.1136/jnnp-2020-323839

33. Panariello A, Bassetti R, Radice A, Rossotti R, Puoti M, Corradin M, et al. Anti-NMDA receptor encephalitis in a psychiatric Covid-19 patient: A case report. Brain, Behaviour, and Immunity 2020; 87:179-181.

34. Dogan L, Kaya D, Sarikaya T, Zengin R, Dincer A, Ozkan I, et al. Plasmapheresis treatment in COVID19-related autoimmunemeningoencephalitis: Case series. Brain, Behavior, and Immunity 2020; 87: 155-158.

35. Sili, U., Kaya, A., \& Mert, A. Herpes simplex virus encephalitis: Clinical manifestations, diagnosis and outcome in 106 adult patients. Journal of Clinical Virology. 2014; 60(2), 112- 
118.doi:10.1016/j.jcv.2014.03.010

36. Arabi YM, Harthi A, Hussein J, Bouchama A, Johani S, Hajeer AH. Severe neurologic syndrome associated with Middle East respiratory syndrome corona virus (MERS-CoV. Infection 2015;43(4): 495-501.

37. Rodriguez-Morales AJ, Cardona-Ospina JA, Gutierrez-Ocampo E, Villamizar-Pena R, Holguin-Rivera Y, Escalera-Antezana JP. Clinical, laboratory and imaging features of COVID-19: a systematic review and meta-analysis. Travel Medicine and Infectious Disease 2020; 34: 101623.

38. Wang L. C-reactive protein levels in the early stage of COVID-19. Medicine et Maladies Infectiuses 2020;50(4): 332-334.

39. N.Chen, M. Zhou, X. Dong, J. Qu, F. Gong, Y. Han, et al.Epidemiological and clinical characteristics of 99 cases of 2019 novel coronavirus pneumonia in Wuhan, China: a descriptive study. Lancet 2020; DOI: 10.1016/S0140-6736(20)30211-7

40. Huang I, Pranata R. Lymphopenia in severe coronavirus disease-2019 (COVID-19): systematic review and meta-analysis. Journal of Intensive care 2020; 8(36):1-10. DOI: 1186/s40560-020-00453-4

41. Li T, Qiu Z, Zhang L, Han Y, He W, Liu Z, et al. Significant changes of peripheral T lymphocyte subsets in patients with severe acute respiratory syndrome. J Infect Dis. 2004;189:648-51.

42. Xu H, Zhong L, Deng J, Peng J, Dan H, Zeng X, et al. High expression of ACE2 receptor of 2019-nCoV on the epithelial cells of oral mucosa. Int J Oral Sci Springer US. 2020;12:1-5.

43. He Z, Zhao C, Dong Q, Zhuang H, Song S, Peng G et al. Effects of severe acute respiratory syndrome (SARS) coronavirus infection on peripheral blood lymphocytes and their subsets. Int J Infect Di 2005; 9: $323-330$

44. Katal S, Balakrishnan S, Gholamrezanezhad A. Neuroimaging and neurologic findings in COVID-19 and other coronavirus infection: A systematic review in 116 patients. J Neuroradiol 2020; DOI: 10.1016/j.neurad.2020.06.007

45. Lau KK, Yu WC, Chu CM, Lau ST, Sheng B, Yuen KY. Possible central nervous system infection by SARS coronavirus. Emerging infectious diseases 2004; 10(2): 342

46. Hwang C. Olfactory neuropathy in Severe Acute Respiratory Syndrome: Report of a case. Acta Neurologica Taiwanica 2006; 15(1):26

47. Canham LJW, Staniaszek LE, Mortimer AM, Nouri LF, Kane NM. Electroencephalographic (EEG) features of encephalopathy of Covid-19: A Case Series. Clin Neurophysiol Pract 2020.

DOI: 1016/j.cnp.2020.06.001

48. Chaudhuri A, Kennedy PGE. Diagnosis and treatment of viral encephalitis. Postgraudate Medical Journal 2002; 78:575-583.

49. Baig AM, Khaleeq A, Ali U, Syeda H. Evidence of the COVID-19 virus targeting the CNS: tissue distribution, host-virus interaction, and proposed neurotropic mechanism. ACS Chem Neurosci 2020; 11(7):995-998. 
50. Abboud H, Abboud FZ, Kharbouch H, Arkha Y, El Abbadi N, El Ouahabi A. COVID-19 and SARS-CoV-2 infection: pathophysiology and clinical effects on nervous system. World Neurosurg 2020; 140:4953.

51. Armanque T., Leypoldt F., Dalmau J. Autoimmune encephalitis as differential diagnosis of infectious encephalitis. Curr Opin Neurol. 2014;27(3):361-368.

52. Sedaghat Z, Karimi N. Guillain Barre syndrome associated with COVID-19 infection: A case report. J Clin Neurosci 2020; 76:233-235.

53. Ropper AH, Brown RH. Adam and Victor's Principle of Neurology, 10th ed. China: McGraw-Hill ; 2014

54. Mahmudpour M, Roozbeh J, Keshavarz M, Farrokhi S, Nabipour I. COVID-19 cytokine strom: The anger of inflammation. Cytokine 2020; 133:155151. DOI: 1016/j.cyto.2020.155151

55. Song P, Li W, Xie J, Hou Y, You C. Cytokine storm induced by SARS-CoV-2. Clin Chim Acta 2020; 509:280-287. DOI: cca.2020.06.017

56. Majid F, Ali M, Somayeh M, Cyrus R. Neurobiology of COVID-19. Journal of Alzheimer's Disease 2020; 76(!):3-19. DOI: 10.3233/JAD-200581.

57. Wu D, Yang XO. TH17 responses in cytokine storm of COVID-19: An emerging target of JAK2 inhibitor. Journal of Microbiology, Immunology, and Infection 2020; 53(3):368-370. DOI: 1016/j.jmii.2020.03.005

\section{Figures}




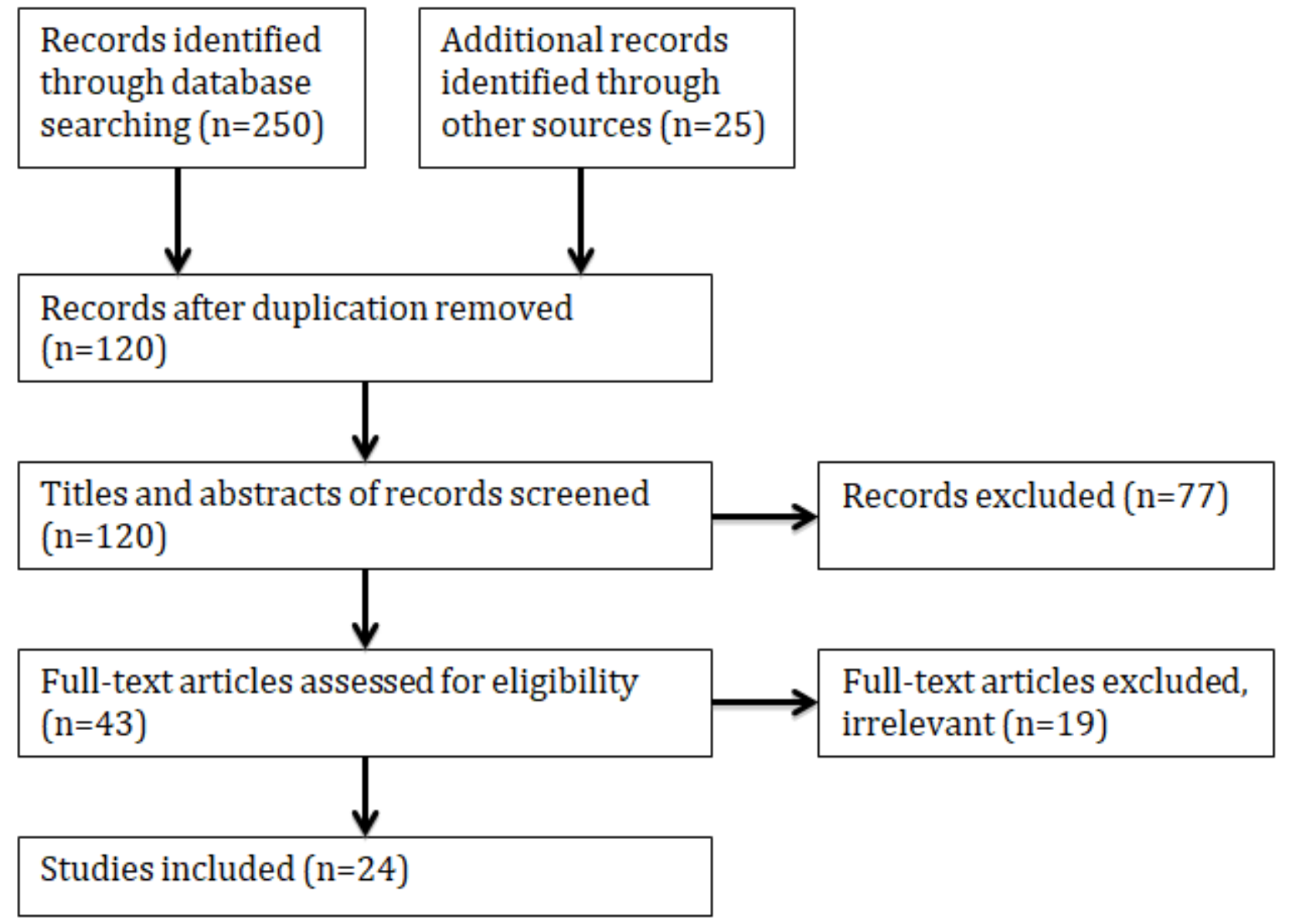

Figure 1

Flow chart of study selection 


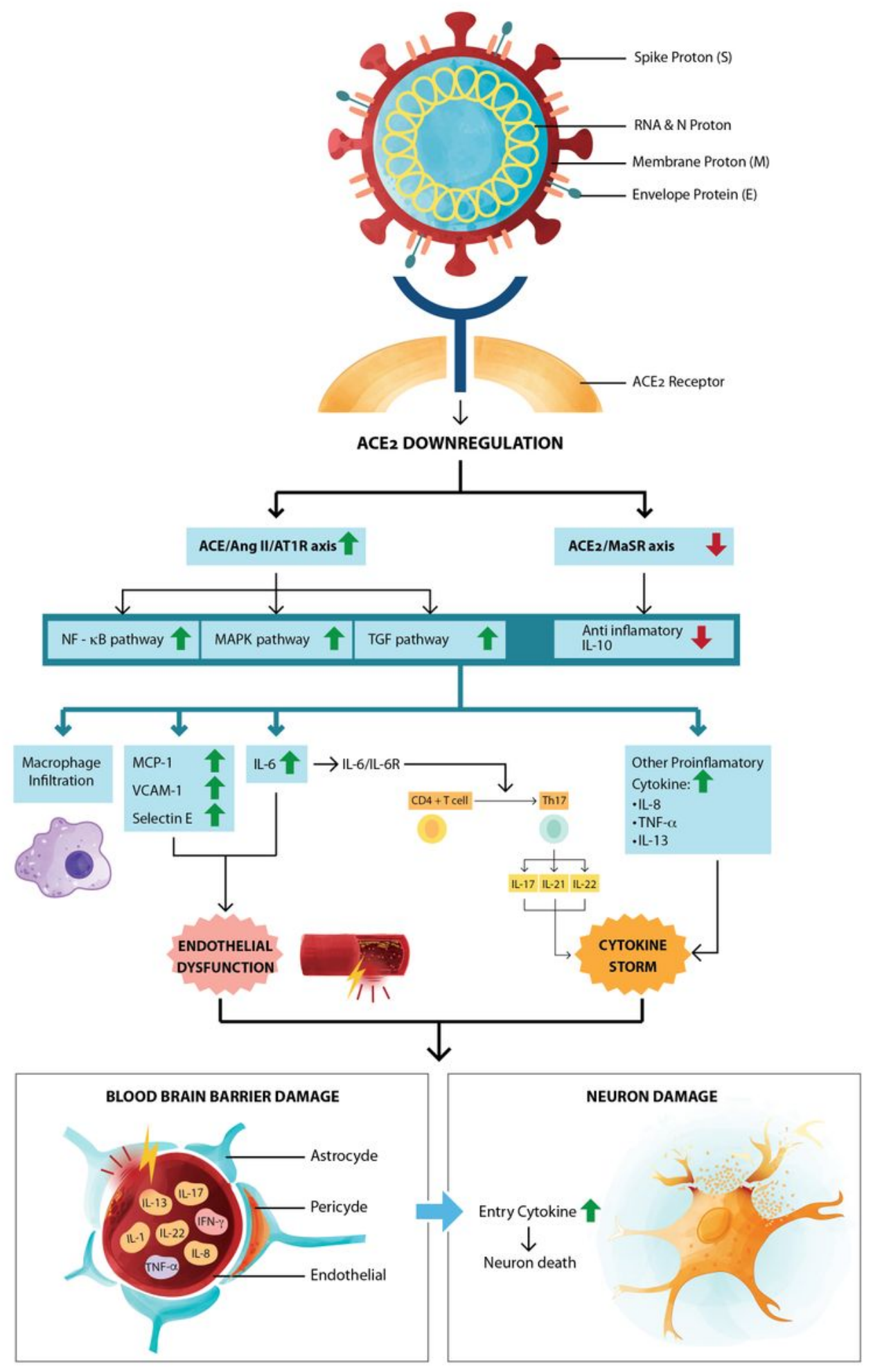

Figure 2

Cytokine-immune mediated inflammation and pathomechanism in COVID-19-associated encephalitis (This image is made by us)

\section{Supplementary Files}


This is a list of supplementary files associated with this preprint. Click to download.

- PRISMA2009checklist.doc 